Syntax Literate : Jurnal Ilmiah Indonesia p-ISSN: 2541-0849

e-ISSN : 2548-1398

Vol. 6, No. 12, Desember 2021

\title{
PENERAPAN STRATEGI REACT BERBANTUAN AUGMENTED REALITY BANGUN RUANG TERHADAP HASIL BELAJAR MATEMATIKA
}

\section{Putu Widiadnyana, Dewa Made Wiharta, I Made Oka Widyantara}

Universitas Udayana (UNUD) Denpasar Bali, Indonesia

Email: widiadnyana11@gmail.com,wiharta@unud.ac.id,oka.widyantara@unud.ac.id

\begin{abstract}
Abstrak
Sistem pembelajaran daring dilakukan untuk mengurangi penyebaran wabah Covid19. Penelitian ini bertujuan untuk mengetahui penerapan strategi pembelajaran yaitu strategi REACT dengan berbantuan media pembelajaran yaitu aplikasi augmented reality pada materi bangun ruang sisi datar. Penelitian ini menggunakan metode eksperimen dengan desain penelitian yaitu pretest-posttest control group design yang dilakukan selama proses pembelajaran daring. Subjek penelitian yaitu siswa kelas VIII di SMP Satu Atap Pejukutan, Kabupaten Klungkung. Penggunaan soal pilihan ganda digunakan untuk mengetahui hasil belajar siswa. Hasil belajar siswa selanjutnya di uji dengan uji ANOVA dan mendapatkan nilai signifikansi yaitu sebesar 0.02 yang lebih kecil dari 0.05 , maka dapat disimpulkan bahwa terdapat adanya perbedaan. Berdasarkan hasil penelitian dapat disimpulkan bahwa penerapan strategi REACT berbantuan aplikasi augmented reality bangun ruang dalam pembelajaran matematika dapat meningkatkan hasil belajar siswa.
\end{abstract}

Kata Kunci: strategi REACT; augmented reality; bangun ruang sisi datar

\section{Abstract}

The online learning system is conducted to reduce the spread of the Covid-19 outbreak. This study aims to find out the application of the learning strategy that is REACT strategy with the help of learning media that is augmented reality application in flat face three dimensional objects. This study uses an experimental method with research design, namely pretest-posttest control group design conducted during the online learning process. The subject of the study was a grade VIII student at SMP Satu Atap Pejukutan, Regency of Klungkung. The use of multiple-choice questions is used to determine student learning outcomes. The results of the students' study were then tested with an ANOVA test and obtained a significance score of 0.02 which is smaller than 0.05, so it can be concluded that there is a difference. Based on the results of the study, it can be concluded that the application of REACT strategies assisted by augmented reality applications to build space in mathematics learning can improve students' learning outcomes.

Keywords: REACT strategy; augmented reality; flat face three dimensional objects

Received: 2021-11-20; Accepted: 2021-12-05; Published: 2021-12-20

How to cite:

E-ISSN:

Published by:
Widiadnyana. P., Dewa Made Wiharta \& I Made Oka Widyantara (2021) Penerapan Strategi React Berbantuan Augmented Reality Bangun Ruang Terhadap Hasil Belajar Matematika. Syntax Literate: Jurnal Ilmiah Indonesia, 6(12). http://dx.doi.org/10.36418/ Syntax-Literate.v6i12.3007 2548-1398

Ridwan Institute 


\section{Pendahuluan}

Pandemi Covid-19 sangat mempengaruhi kegiatan pembelajaran di sekolah yang menyebabkan proses pembelajaran yang biasanya dilakukan tatap muka menjadi daring.

Proses pembelajaran daring dilakukan dengan memberikan materi pembelajaran oleh guru menggunakan e-learning dan siswa mengakses $e$-learning untuk mengetahui kegiatan pembelajaran yang dilakukan di rumah. Kegiatan pembelajaran daring dilakukan untuk mengurangi penyebaran virus corona, akan tetapi dalam kegiatan tersebut muncul kendala-kendala selama proses kegiatan pembelajaran seperti siswa yang belum terbiasa akan suasana dalam pembelajaran daring (Purwanto et al., 2020), peserta didik kurang terawasi dengan baik selama proses pembelajaran daring (Sadikin \& Hamidah, 2020), dan kurangnya pemahaman siswa terhadap materi yang diberikan sehingga timbul sifat malas dan bosan selama pembelajaran (Fahruni \& Wiryosutomo, 2021). Pada mata pembelajaran matematika, permasalahan tersebut muncul sehingga mengakibatkan kurangnya motivasi belajar siswa yang akan berdampak pada tidak tercapainya tujuan pembelajaran yang optimal.

Berdasarkan hasil pengamatan peneliti di SMP Satu Atap Pejukutan Kabupaten Klungkung pada Tahun ajaran 2019/2020 pada semester II diketahui bahwa kurangnya media pembelajaran inovatif yang digunakan selama proses pembelajaran daring. Permasalahan tersebut menimbulkan kurangnya minat siswa dalam proses pembelajaran sehingga penyampaian materi terasa kurang maksimal. Pembelajaran matematika memiliki tujuan yaitu mempersiapkan siswa agar mampu menyelesaikan permasalahan yang berkaitan dengan matematika dengan kemampuan berpikir logis, cermat dan kritis. Kemampuan dalam menyelesaikan permasalahan merupakan kemampuan matematis yang sangat penting bagi siswa dan harus dikembangkan oleh guru (Dwi, Rachmani, \& Nino, 2021). Kemampuan pemecahan masalah berkaitan dengan kecerdasan logis matematis manusia (Rinawati \& Ratu, 2021). Salah satu materi yang dipelajari pada mata pelajaran matematika kelas VIII yang menggunakan kemampuan pemecahan masalah adalah bangun ruang sisi datar. Pada materi ini terkadang siswa mengalami kesulitan dalam memecahkan permasalahan seperti soal-soal.

Dalam mempelajari matematika, diperlukan berbagai kemampuan dalam menangani persoalan yang ada seperti kemampuan menghafal rumus, kemampuan ketelitian dan keyakinan dalam menyelesaikan persoalan matematika (Warni, Binasar, \& Silondae, 2018). Kemampuan tersebut didapatkan dari pengajaran dan bimbingan oleh guru kepada siswa dengan adanya interaksi dan kegiatan pembelajaran yang kondusif. Untuk mencapai kegiatan pembelajaran yang kondusif maka guru merancang pembelajaran dengan cara pemberian materi yang dilakukan secara bertahap dan mudah dimengerti oleh siswa (Napsawati, 2020). Dalam perancangan pembelajaran, penggunaan strategi pembelajaran dan media pembelajaran yang sesuai mampu mempengaruhi suasana dalam belajar dan hasil belajar siswa (Sirait \& Apriyani, 2020).

Penggunaan strategi pembelajaran dan media pembelajaran dalam kegiatan belajar mampu mencapai tujuan pembelajaran yang sudah ditentukan. Pemilihan strategi pembelajaran dan media pembelajaran disesuaikan dengan kondisi pembelajaran saat 
ini. Salah satu strategi pembelajaran yang berpusat pada siswa adalah strategi REACT. Strategi REACT memiliki tahapan-tahapan yang terdiri dari Relating (Mengaitkan), Experiencing (Mengalami), Applying (Menerapkan), Cooperating (Bekerja sama), Transferring (Mentransfer). Strategi ini merupakan model pembelajaran kontekstual yang mengaitkan teori dengan kehidupan nyata. Dalam penerapan strategi REACT dalam pembelajaran, siswa akan lebih berperan aktif dalam mengkonstruksi pengetahuan mereka. Hasil penelitian oleh (Sari \& Iza, 2020) mengungkapkan bahwa penggunaan strategi pembelajaran yaitu strategi REACT dapat mengatasi dan membantu dalam proses kegiatan pembelajaran.

Media pembelajaran yang digunakan dalam kegiatan pembelajaran harus disesuaikan dengan kebutuhan siswa. Dengan adanya media pembelajaran, dapat mengatasi permasalahan pembelajaran dan menciptakan proses pembelajaran yang interaktif (Nuri \& Khairunnisa, 2021). Media pembelajaran saat ini sudah banyak memanfaatkan teknologi dalam proses pengembangannya. Augmented reality merupakan teknologi yang digunakan dalam pengembangan media pembelajaran untuk kegiatan belajar yang lebih kreatif. Augmented reality merupakan teknologi yang menggabungkan dunia digital dengan dunia nyata, dimana objek 3D bisa ditampilkan di lingkungan nyata (Saca, 2021). Media berbasis augmented reality mampu membuat siswa dapat secara langsung berinteraksi dengan objek yang divisualisasikan secara real-time. Penelitian yang dilakukan oleh (Noviansyah \& Saiyar, 2021) mendapatkan hasil bahwa aplikasi augmented reality sebagai media pembelajaran dapat membantu dalam pembelajaran dalam bentuk tampilan 3D dan penelitian yang dilakukan oleh (Alamsyah \& Krisdiawan, 2021) aplikasi augmented reality mampu memudahkan siswa dalam memahami materi dan meningkatkan minat belajar siswa.

Berdasarkan uraian permasalahan yang telah dipaparkan di atas, maka peneliti melakukan penelitian dengan tujuan penelitian yaitu menerapkan strategi REACT berbantuan augmented reality materi bangun ruang pada mata pelajaran matematika. Augmented reality yang akan digunakan sebagai media berupa aplikasi android yang sudah disesuaikan dengan kebutuhan siswa. Penelitian ini mempunyai pokok pembahasan yaitu perbandingan penerapan pembelajaran menggunakan strategi REACT berbantuan augmented reality dengan pembelajaran konvensional yaitu pemberian materi dan tanya jawab selama proses pembelajaran daring.

\section{Metode Penelitian}


Penelitian ini menggunakan metode yang dapat dilihat pada Gambar

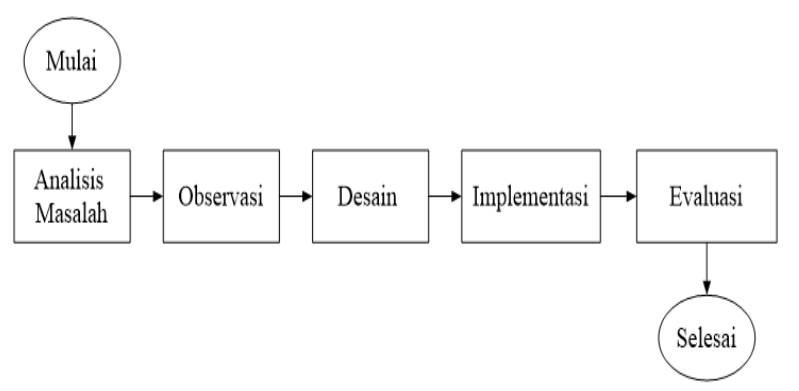

Gambar 1

\section{Metode Penelitian}

Analisis permasalahan dilakukan untuk mengetahui adanya permasalahan atau kendala yang terjadi selama proses pembelajaran daring. Berdasarkan hasil pengamatan, diketahui selama proses pembelajaran daring memiliki kendala-kendala dalam penerapannya seperti kurangnya media pembelajaran inovatif yang digunakan selama proses pembelajaran daring dan perencanaan kegiatan belajar yang dapat menarik minat siswa untuk belajar. Berdasarkan permasalahan yang ada, maka diterapkanlah strategi REACT sebagai strategi pembelajaran untuk merancang kegiatan pembelajaran dan penggunaan aplikasi augmented reality bangun ruang sebagai media pembelajaran yang memiliki kelebihan dapat memvisualkan objek 3D dan siswa dapat berinteraksi dengan media secara langsung.

Kegiatan observasi di SMP Satu Atap Pejukutan, Kabupaten Klungkung dilakukan untuk mengetahui kegiatan belajar mengajar dan kondisi siswa. Metode pengumpulan data dilakukan dengan cara wawancara, pencatatan dokumen, tes, dan kuesioner. Peneliti melakukan wawancara kepada guru mata pembelajaran matematika sebagai narasumber secara langsung dan memberikan kuesioner kepada siswa menggunakan google form untuk mengetahui kondisi awal siswa seperti perangkat yang digunakan selama proses pembelajaran daring dan kendala-kendala selama proses pembelajaran daring. Data yang sudah dikumpulkan selanjutnya diproses sebagai dasar penerapan penelitian.

Penelitian ini merupakan penelitian eksperimen dengan desain pretest-posttest control group design. Populasi yang digunakan dalam penelitian ini adalah seluruh siswa kelas VIII di SMP Satu Atap Pejukutan, Kabupaten Klungkung pada Tahun ajaran 2019/2020 pada semester II sebanyak 39 siswa. Metode pengambilan sampel menggunakan metode simple random sampling yang mendapatkan hasil kelas VIII A sebagai kelompok kontrol dengan jumlah siswa sebanyak 20 orang dan Kelas VIII B mendapatkan kelompok eksperimen dengan jumlah siswa sebanyak 19 orang.

Implementasi diawali dengan menyiapkan persiapan awal yang terdiri dari RPP (Rencana pelaksanaan pembelajaran) pada masing-masing kelompok dan instrumen tes hasil belajar. Penyesuaian RPP yang didapatkan oleh guru selanjutnya dirubah berdasarkan penerapan pada masing-masing kelompok dan instrumen tes hasil belajar diawali dengan pembuatan soal yang akan digunakan pada saat pre-test dan post-test. 
Pembuatan soal yang akan digunakan, akan di uji cobakan terlebih dahulu oleh siswa kelas IX untuk mengetahui apakah soal sudah dapat digunakan sebagai instrumen tes hasil belajar. Hasil dari uji coba soal akan dianalisis menggunakan uji validitas tes, reliabilitas tes, taraf kesukaran dan daya beda. Penerapan kegiatan belajar dalam pembelajaran daring akan disesuaikan dengan RPP yang sudah disusun ke dalam $e$ learning. Awal proses pembelajaran, akan diberikan pre-test pada masing-masing kelompok untuk mengetahui kemampuan awal siswa sebelum diberikan perlakuan. Setelah pemberian perlakuan dan pemberian materi telah selesai, selanjutnya akan diberikan post-test untuk mengetahui kemampuan siswa dalam menyerap materi yang telah diberikan.

Hasil belajar siswa selanjutnya dilakukan evaluasi dengan menggunakan uji ANOVA satu arah. Uji anova digunakan karena dalam penelitian ini variabel bebasnya pada model pembelajaran dan variabel terikatnya pada hasil belajar. Sebelum melakukan uji ANOVA satu arah, dilakukan uji prasyarat terlebih dahulu yaitu uji normalitas dan uji homogenitas.

\section{Hasil dan Pembahasan}

Penelitian eksperimen ini menggunakan dua model pembelajaran yaitu model pembelajaran konvensional dengan berbantuan media powerpoint pada kelompok kontrol dan model pembelajaran kontekstual dengan strategi REACT berbantuan media pembelajaran augmented reality pada kelompok eksperimen. Sebelum diterapkan model pembelajaran kepada masing-masing kelompok, siswa diberikan pre-test terlebih dahulu untuk mengukur pengetahuan awal siswa dan setelah pemberian materi selanjutnya siswa diberikan post-test untuk mengetahui kemampuan siswa dalam memahami materi. Hasil dari pre-test dan post-test dapat dilihat pada Tabel 1.

Tabel 1

Rekapitulasi Hasil Penilaian

\begin{tabular}{lllll}
\hline \multirow{2}{*}{ Data } & \multicolumn{2}{c}{ Pre-test } & \multicolumn{2}{c}{ Post-test } \\
\cline { 2 - 5 } & $\begin{array}{l}\text { Kelas } \\
\text { Kontrol }\end{array}$ & $\begin{array}{l}\text { Kelas } \\
\text { Eksperimen }\end{array}$ & $\begin{array}{l}\text { Kelas } \\
\text { Kontrol }\end{array}$ & $\begin{array}{l}\text { Kelas } \\
\text { Eksperimen }\end{array}$ \\
\hline Skor Total & 997 & 920 & 1587 & 1610 \\
\hline Skor Rata-rata & 49.11 & 48.42 & 79.00 & 84.74 \\
\hline Standar Deviasi & 11.97 & 13.81 & 7.52 & 7.40 \\
\hline
\end{tabular}

Berdasarkan tabel 1, diketahui bahwa skor total pre-test (997) dengan skor ratarata (49.11) pada kelas kontrol lebih tinggi dibandingkan dengan kelas eksperimen dengan total skor total (920) dengan skor rata-rata (48.42). Sedangkan, skor total posttest kelas eksperimen (1610) dengan skor rata-rata (84.74) lebih tinggi dibandingkan dengan skor total kelas kontrol (1587) dengan skor rata-rata (79.00). Tabel di atas menunjukkan bahwa kelas kontrol dan eksperimen mengalami peningkatan skor setelah diberikan penerapan pembelajaran. Terdapat perbedaan peningkatan skor pada kelas kontrol dan kelas eksperimen karena adanya perlakuan yang berbeda. Skor rata-rata pada kelas kontrol mengalami peningkatan dengan selisih pre-test dan post-test sebesar 
29.89. Sedangkan, skor rata-rata pada kelas eksperimen mengalami peningkatan dengan selisih pre-test dan post-test sebesar 36.32 .

Hasil belajar siswa pada masing-masing kelompok selanjutnya di uji prasyarat ANOVA satu arah. Sebelum melakukan uji ANOVA satu arah, perlu dilakukan uji prasyarat analisis data terlebih dahulu yang meliputi uji normalitas dan uji homogenitas. Uji normalitas adalah sebuah uji yang dilakukan untuk mengetahui apakah data masingmasing kelompok berdistribusi normal atau tidak. Metode yang digunakan untuk melakukan uji normalitas adalah dengan menggunakan uji Shapiro-Wilk. Dalam penelitian ini menggunakan bantuan perangkat lunak IBM SPSS Statistic versi 26. Berikut hasil dari uji normalitas seperti terlihat pada Tabel 2.

Tabel 2

Hasil Uji Normalitas

\begin{tabular}{lllll}
\hline \multirow{2}{*}{ Statistik } & \multicolumn{2}{c}{ Pre-test } & \multicolumn{2}{c}{ Post-test } \\
\cline { 2 - 5 } & Kelas Kontrol & $\begin{array}{l}\text { Kelas } \\
\text { Eksperimen }\end{array}$ & Kelas Kontrol & $\begin{array}{l}\text { Kelas } \\
\text { Eksperimen }\end{array}$ \\
\hline Shapiro-Wilk & 0.959 & 0.944 & 0.943 & 0.928 \\
\hline Sig & 0.555 & 0.307 & 0.298 & 0.161 \\
\hline Taraf Signifikan & & \multicolumn{3}{c}{0.05} \\
\hline Keputusan & Terdistribusi & Terdistribusi & Terdistribusi & Terdistribusi \\
& Normal & Normal & Normal & Normal \\
\hline
\end{tabular}

Untuk membuktikan data berdistribusi normal atau tidak setelah melakukan uji normalitas adalah dengan membandingkan nilai signifikansi hasil uji normalitas dengan taraf signifikansi 5\% atau sebesar 0.05. Jika nilai signifikansi hasil dari pengujian lebih kecil dari 0.05 maka data dapat dikatakan tidak berdistribusi normal, sedangkan jika hasil dari pengujian lebih dari 0.05 maka data dapat dikatakan berdistribusi normal. Berdasarkan hasil uji normalitas yang telah dilakukan, nilai signifikansi yang didapatkan lebih besar dari 0.05 , maka hasil pengujian tersebut dapat disimpulkan bahwa data berdistribusi normal.

Selanjutnya uji homogenitas dilakukan untuk mengetahui apakah sekumpulan data yang akan dianalisis berasal dari populasi yang tidak jauh berbeda keragamannya atau tidak dalam penelitian. Dalam penelitian ini, keragaman yang dimaksud adalah tingkat kemampuan peserta didik. Uji Levene Statistic adalah metode yang digunakan dalam penelitian ini untuk menguji homogenitas dilakukan dengan bantuan perangkat lunak IBM SPSS Statistic versi 26. Hasil yang didapatkan dari uji homogenitas seperti yang terlihat pada Tabel 3.

Tabel 3

Hasil Uji Homogenitas

\begin{tabular}{|c|c|c|}
\hline \multirow{2}{*}{ Statistik } & Pre-test & Post-test \\
\hline & Kelas Kontrol Kelas Eksperimen & Kelas Kontrol Kelas Eksperimen \\
\hline Levene Statistic & 0.004 & 0.078 \\
\hline Sig & 0.947 & 0.781 \\
\hline Taraf Signifikan & & \\
\hline Keputusan & Data Homogen & Data Homogen \\
\hline
\end{tabular}


Untuk varian bersifat homogen atau tidak setelah dilakukan uji homogenitas adalah dengan membandingkan nilai signifikansi hasil uji homogenitas dengan taraf signifikansi $5 \%$ atau sebesar 0.05 . Jika nilai signifikansi hasil dari pengujian kurang dari 0.05 maka dapat dikatakan varian tidak homogen, sedangkan jika nilai signifikansi hasil lebih dari 0.05 maka dapat dikatakan varian homogen. Berdasarkan hasil uji homogenitas yang telah dilakukan, nilai signifikansi yang didapatkan lebih besar dari 0.05, maka dapat disimpulkan bahwa varian bersifat homogen.

Setelah semua prasyarat analisis untuk pengujian terpenuhi, maka langkah selanjutnya adalah melakukan uji perbedaan dengan menggunakan uji statistik ANOVA satu arah. Uji perbedaan ini dilakukan untuk mengetahui apakah terdapat perbedaan signifikan terhadap hasil percobaan yang telah dilakukan. Dalam penelitian ini untuk menguji ANOVA dilakukan dengan bantuan perangkat lunak IBM SPSS Statistic versi 26. Hasil uji ANOVA satu arah terlihat pada Tabel 4.

\section{Tabel 4}

\section{Hasil Uji Statistik ANOVA}

\begin{tabular}{lccccc}
\hline & Sum of Squares & df & Mean Square & F & Siq. \\
\hline Between Groups & 304.411 & 1 & 304.411 & 5.575 & 0.024 \\
\hline Within Groups & 2020.358 & 37 & 54.604 & & \\
\hline Total & 2324.769 & 38 & & & \\
\hline
\end{tabular}

Untuk mengetahui apakah terdapat perbedaan atau tidak setelah melakukan uji ANOVA satu arah dengan cara membandingkan nilai signifikansi 5\% atau sebesar 0.05 . Jika nilai signifikansi hasil dari pengujian lebih kecil dari 0.05 maka dapat dikatakan bahwa terdapat perbedaan, sedangkan jika nilai signifikansi hasil lebih besar dari 0.05 maka dapat dikatakan bahwa tidak terdapat perbedaan. Berdasarkan hasil uji ANOVA yang telah dilakukan, nilai signifikansi yang didapatkan sebesar 0.02 yang lebih kecil dari 0.05, maka dapat disimpulkan bahwa terdapat perbedaan. Dari pernyataan tersebut dapat diambil kesimpulan terdapat perbedaan signifikan antara peserta didik yang menggunakan media pembelajaran augmented reality dengan strategi REACT dengan peserta didik yang tidak menggunakan media pembelajaran augmented reality dengan strategi REACT.

\section{Kesimpulan}

Penelitian ini memiliki tujuan untuk mengetahui penerapan strategi REACT berbantuan augmented reality materi bangun ruang mempengaruhi hasil belajar siswa jika dibandingkan dengan menggunakan pembelajaran konvensional. Berdasarkan hasil analisis menggunakan ANOVA satu arah, dapat disimpulkan bahwa yang berarti terdapatnya perbedaan dalam penerapan pembelajaran. Perbedaan ini timbul dikarenakan lebih aktifnya siswa pada kelompok eksperimen dalam kegiatan pembelajaran daring sehingga peningkatan hasil belajar siswa pada kelas eksperimen lebih tinggi dibandingkan dengan kelas kontrol yang menunjukkan bahwa kelas eksperimen yang diberikan perlakuan berupa penerapan media pembelajaran augmented 
reality dengan strategi REACT memiliki peningkatkan yang lebih tinggi dibandingkan dengan kelas kontrol.

\section{BIBLIOGRAFI}

Alamsyah, N., \& Krisdiawan, R. A. (2021). Pembangunan Aplikasi Sebagai Media Pembelajaran Bangun Ruang Tingkat SD / SMP Dengan Menggunakan Metode Marker Augmented Reality. Jurnal Nuansa Informatika, 15(1), 23-31. Google Scholar

Dwi, E., Rachmani, N., \& Nino, D. (2021). Kajian Teori : Pengembangan Bahan Ajar Matematika Berbantuan GeoGebra untuk Meningkatkan Kemampuan Pemecahan Masalah Matematis Melalui Model Pembelajaran Preprospec Berbantuan TIK pada Materi Bangun Ruang Sisi Datar. Prisma, 4, 179-188. Google Scholar

Fahruni, F. E., \& Wiryosutomo, H. W. (2021). Analisis Faktor-Faktor Penyebab Perilaku Malas Belajar Daring Saat Pandemi Covid-19 Pada Siswa Kelas XII SMA Negeri 1 Menganti Gresik. Jurnal BK Unesa, 12, 22-36. Google Scholar

Napsawati. (2020). Analisis Situasi Pembelajaran Ipa Fisika Dengan Metode Daring Di Tengah Wabah Covid-19. Karst :Jurnal Pendidikan Fisika Dan Terapannya, 3(1), 96-102. Google Scholar

Noviansyah, M., \& Saiyar, H. (2021). Aplikasi Android Pembelajaran Mengenal Planet Untuk Murid Paud Berbasis Augmented Reality. Jurnal AKRAB JUARA, 6(2), 4149. Google Scholar

Nuri, R., \& Khairunnisa. (2021). Efektivitas Penggunaan Media Pembelajaran Big book Subtema Indahnya Keberagaman Budaya Negeriku. Tarbiyah Wa Ta'lim: Jurnal Penelitian Pendidikan Dan Pembelajaran, 8(1), 49-60. Google Scholar

Purwanto, A., Pramono, R., Asbari, M., Santoso, P. B., Wijayanti, L. M., Choi, C. H., \& Putri, R. S. (2020). Studi Eksploratif Dampak Pandemi COVID-19 Terhadap Proses Pembelajaran Online di Sekolah Dasar. EduPsyCouns: Journal of Education, Psychology and Counseling, 2(1), 1-12. Retrieved from https://ummaspul.e-journal.id/Edupsycouns/article/view/397 Google Scholar

Rinawati, R., \& Ratu, N. (2021). Analisis Kemampuan Pemecahan Masalah Siswa SMP Kelas VIII Pada Materi Bangun Ruang Sisi Datar Ditinjau dari Kecerdasan Logis Matematis. Jurnal Cendekia: Jurnal Pendidikan Matematika, 5(2), 1223-1237. Google Scholar

Saca, A. (2021). Penerapan Marker-Based Augmented Reality Sebagai Media Pembelajaran Tata Surya. JIKA (Jurnal Informatika) Universitas Muhammadiyah Tangerang, 33-40. Google Scholar

Sadikin, A., \& Hamidah, A. (2020). Pembelajaran Daring di Tengah Wabah Covid-19. BIODIK: Jurnal Ilmiah Pendidikan Biolog, 6(2), 214-224. Google Scholar 
Penerapan Strategi React Berbantuan Augmented Reality Bangun Ruang Terhadap Hasil Belajar Matematika

Sari, N. K., \& Iza, N. (2020). Analisis Kebutuhan Buku Ajar Perkembangan Hewan Berbasis Model REACT (Relating, Experiencing, Applying, Cooperating, Transfering). JPB (Jurnal Pendidikan Biologi), 12(1), 57-63. Google Scholar

Sirait, E. D., \& Apriyani, D. D. (2020). Pengaruh Penggunaan Strategi Pembelajaran Aktif Icm (Index Card Match) Terhadap Hasil Belajar Matematika. JPMI (Jurnal Pendidikan Matematika Indonesia), 5(1), 46-48. Google Scholar

Warni, A., Binasar, S. S., \& Silondae, D. P. (2018). Motivasi Belajar Siswa Pada Pembelajaran Matematika SMP Negeri 2 Mawasangka. Jurnal BENING (Belajar Bimbingan Dan Konseling), 1(2), 11-18. Google Scholar

\section{Copyright holder:}

Putu Widiadnyana, Dewa Made Wiharta, I Made Oka Widyantara (2021)

First publication right:

Syntax Literate: Jurnal Ilmiah Indonesia

This article is licensed under: 